\title{
THE. NATURE, DISTRIBUTION AND RELATIONSHIP OF ARCHAEAN TERRANES IN EASTERN BRAZIL
}

\section{A. BERNASCONI*}

\begin{abstract}
This is a study of the general geological characteristics, distribution and relationship of the major Archacan terranes of eastern Brazil. It also includes a concise description of several lithostratigraphic sequences of typical greensione signat ure and associated granite-gneisses belonging the São Francisco Craton, which is interpreted as the only Archaean cratonic area within the region under consideration. The greenstone successions, however, present a poorly preserved stratigraphy, due mainly to the emplacement of gneissic tonalite, and granite plutons, and to the proportion of volcanics, particularly of komatiitic composition, is low, while aquagene tuffs and associated sediments form the most important lithological components.

The high-grade metamorphic terranes, subjected to granulite facies of regional metamorphism mostly during the late Archaean $(\sim 2.7 \mathrm{Ga})$, are represented by the Jequié and Goiás mobile belts, and the Santa Catarina and Santa Maria Chico complexes. In the first two belts, granite-greenstone nucleus display relatively well preserved stratigraphic sequences exist within the high-grade metamorphites as isolated remnants, while adjacent areas have been reworked by a intense tectono-thermal event. In compatison to Archaean terranes in other parts of the world, the Brazilian counterparts are rather different in features such as transitional boundaries, fragmentary patterns and poorly preserved greenstone sequences.
\end{abstract}

RESUMO Este trabalho estuda as características geológicas gerais, a distribuição e a relação dos principais terrenos arqueanos do Leste brasileiro. Ele inclui também a descrição de muitas seqüuencias estratigráficas do típico greenstone-belt e de gnaisses graniticos associados, pertencentes ao Cráton do São Francisco o que pode ser interpretado como a única área cratônica arqueana dentro da região em consideração. A sucessão dos greenstones, no entanto, apresenta uma estratigrafia pobremente preservada, devido principalmente à inserção de gnaisses tonalíticos e granitos plutônicos, e à proporção de vulcânicas, principalmente de composição komatítica, ser baixa, enquanto que os tufos e sedimen tos associados formam o mais importante dos componentes litológicos.

Os terrenos metamórficos de alto grau, sujeitos ao fácies granulítico, formados principalmente durante o último período arqueano $(\sim 2.7 \mathrm{Ga})$, estão representados pelos cinturōes móveis de Jequié e Goiás e os complexos de Santa Catarina e Santa Maria Chico. Nos dois primeiros cinturões, os núcleos de terrenos de greenstone-granitos mostram sequêencias estratigxáficas bem preservadas, que existem dentro dos metamorfitos de alto grau como remanescentes isolados, enquanto que as áreas adjacentes têm sido retrabalhadas por um evento tectono-termal intenso. Em comparação com os terrenos arqueanos de outros lugares do mundo, os terrenos brasileiros apresentam certas diferenças, tais como, contatos transicionais, aspecto de fragmentação intensa e sequêencias de greenstone pobremente preservadas.

INTRODUCTION The regional and detailed geological investigations carried out in the last ten years in the eastern part of Brazil, have resulted in the recognition of several major Archaean domains with confirmed radiometric ages older than $2.5 \mathrm{Ga}$ (Fig. 1).

A high degree of uncertainty, however, remains with respect to the boundaries and relationship between these domains, due mainly to the lack of exposure in critical areas and also to the substantial reworking of the earlier lithostratigraphic sequences by the superimposition of younger tectono-thermal events. Thus, the definition and extent of cratonic and mobile zones of Archaean age in the eastern region of Brazil are inferred in some areas, rather than based on direct geological observation. However, despite the limitations, imposed by the nature of these terranes, there is evidence for separating a major cratonic area - the São Francisco Craton - and at least two mobile zones: the Jequié and Goiás belts. In addition, granitegreenstone nucleus and rather small high-grade metamorphic complexes are known within the various Archaean environments of eastern Brazil.

Most of the low-grade granite-greenstone belts in central eastern Brazil are integral members of the São Francisco
Craton, but a few relatively well preserved granite-greenstone nucleus also exist in the adjacent high-grade mobile areas bordering the craton. As their geological settings differ considerably, the latter areas will be described separately.

THE SÃO FRANCISCO CRATON Although this Archaean domain is regarded as one of the best investigated areas among Brazilian ancient terranes, there are still many doubts, especially in relation to its boundaries and its structural relationship with adjacent Precambrian terranes, due basically to the presence of extensive sedimentary cover sequences of Precambrian and Phanerozoic ages. In a recent review (Bernasconi 1983) applying the Anhaeusser et al. (1969) cratonic criterion, the boundaries of the craton as defined by Almeida (1967) and latter revised by Almeida (1977) were substantially modified, such that a large part of its northeast extension was separated and redefined as probably forming part of two different geotectonic units, the Jequié Mobile Belt and the São Lurs-Paramirim Province (Figs. 2 and 3).

A significant portion of the exposed areas of the São Francisco Craton is occupied by a variety of granite-gneiss 


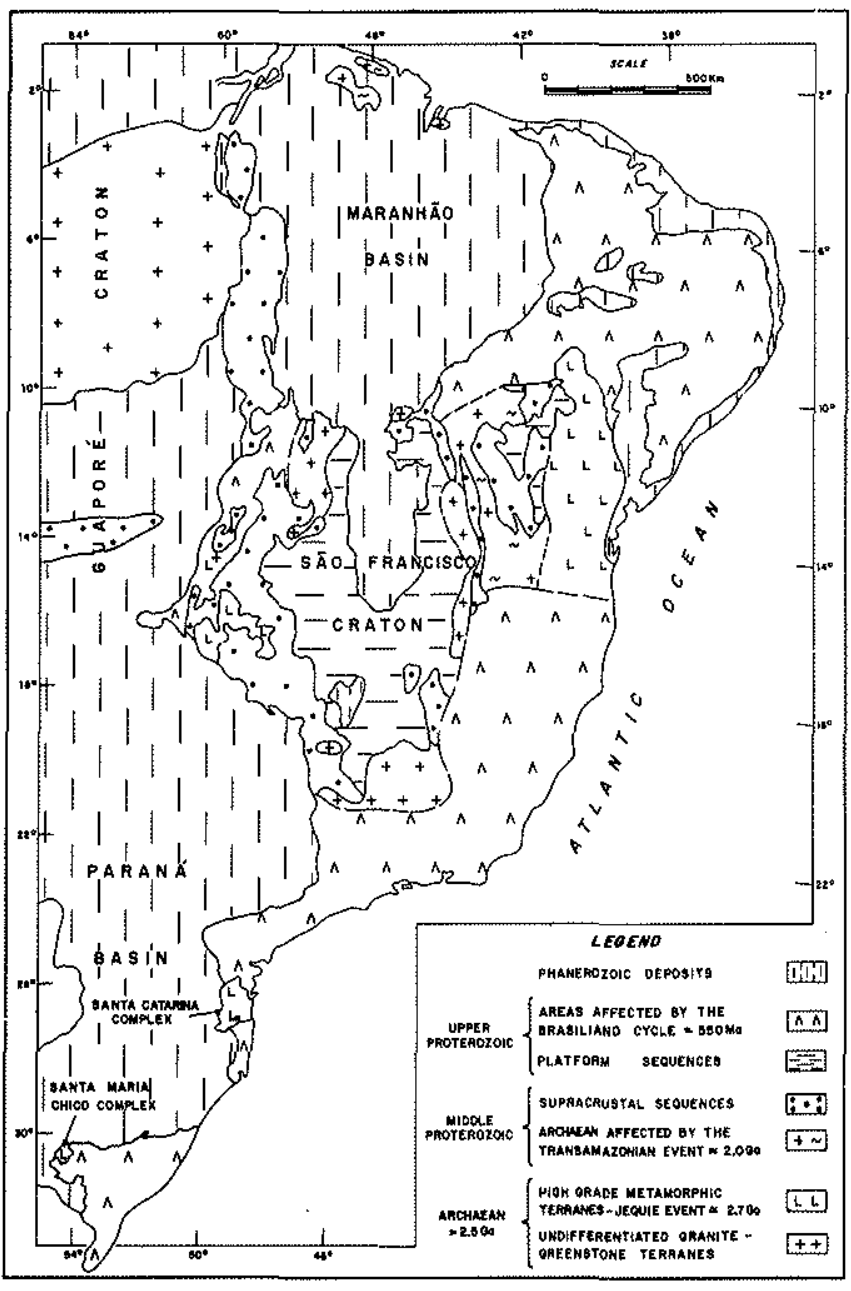

Figure 1-Map geotectonic units

rocks, which have received relatively less at tention than the areas of greenstone-type lithostratigraphic units. Migmatitic rocks associated with granitoid-gneisses are also present in the southeast part of the craton.

Apart from the better studied southeast region, radiometric age determinations have only been carried out on rocks from a small area north of Colinas, on the central west flank of the craton, giving a $\mathrm{Rb}-\mathrm{Sr}$ isochron of approximately $3.2 \mathrm{Ga}$ (Tassinari et al. 1981).

Much of the geological data, presently available for the craton, is derived from areas containing partly preserved greenstone successions such as Piũi, Fortaleza de Minas, Quadrilátero Ferrífero (Iron Quadrangle), Gouveia, Riacho dos Machados and Dianópolis (Fig. 2). These sequences commonly show rather depleted stratigraphic successions in which komatiitic rocks and acid volcanics are only present in restricted quantities, and well developed metatholeiite units may also be lacking. Conversely, tuffaceous lithologies and associated metasediments are cornparatively abundant.

The Pini succession is described (Fritzons et al. 1980, Biondi \& Schrank 1980) as a volcanorsedimentary sequence largely composed of metatholeiitic basalts, with intercalated tuffaceous material and minor acid to intermediate metavolcanics.
The main lithostratigraphic characteristics of the Fortaleza de Minas belt (Teixeira \& Danni 1979 a,b) include the presence of significant quantities of greenschists (metatuffs) with oxide-facies banded-iron formations and minor serpentinized ultramafic rocks of a possible komatiitic affiliation. Besides, several small differentiated mafic to ultramafic intrusives are known in this belt.

The largest of the greenstone successions, known within the craton, is the Rio das Velhas greenstone belt, which underlies the Proterozoic sequences of the Iron Quadrangle district. It is composed of two major units, the Nova Lima Group and the overlying Maquine Group (Dorr et al. 1957, Dorr 1969). The former group consists essentially of a schistose assemblage mainly developed from a volcanosedimentary sequence rich in alumina, iron and silica subjected to a low-grade regional metamorphism (Herz 1978). Various types of banded iron-formation, small bodies of deeply altered mafic to ultramafic rocks, including a prominent serpentinite unit displaying spinifex texture south of Santa Barbara, Quebra-Osso Group, and subordinate pillowed mafic volcanics, are also present in the Nova Lima Group.

The Maquiné Group is almost entirely formed by psammitic metasediments, making its lithological characteristics similar to the Lower Proterozoic sequences, also present in the area. Thus, in the author's opinion, the Archaean age of this group remains uncertain.

Archaean granite-gneiss rocks are also well exposed in this area, and some of them, particularly the Bação Complex, show excellent field evidence of their intrusive character in the rocks of the Nova Lima Group. The available geochronological data (Herz 1970, Cordani \& Teixeira 1979) indicate $\mathrm{Rb}$-Sr age between 2.8 and $2.7 \mathrm{Ga}$.

The other greenstone successions of Gouveia, Riacho dos Machados and Dianópolis (Fig. 2), are relatively less investigated and they seem to represent only poorly preserved relics. However, a schistose sequence, partly similar to that of the Nova Lima Group, is exposed at Gouveia and Riacho dos Machados, and in the latter area sheared greenstones, probably metatholeiitic volcanics, are also present (Bernasconi 1983).

The existence of an Archaean volcano-sedimentary sequence of greenstone affiliation in the vicinity of Dianópolis (Goiás) was reported by Costa et al. (1976). In general, this belt is composed of mica schists, oxide-facies banded iron-formation, and irregular outcrops of massive basic metavolcanics. Large granitic bodies of possible Archaean age appear to intrude the volcano-sedimentary sequence.

HIGH-GRADE GRANULITE-GNEISS TERRANES The presence of high-grade metamorphic terranes has been confirmed in several areas of eastern Brazil, including the Jequié and Goiás mobile belts, and the Santa Catarina and Santa Maria Chico complexes (Fig. 1).

The Jequié Niobile Belt A substantial portion of eastern Bahia state is underlain by high-grade metamorphic rocks, mainly within the granulite and upper amphibolite facies (Fujimori 1968, Sighinolfi 1970, Oliveira et al. 1982). In the northern part of this belt, the folded structure of the Caraiba Complex (Barbosa 1970), which consists predominantly of migmatites, banded gneisses, schists and subordinate mafic to ultramafic bodies, seem to coexist 


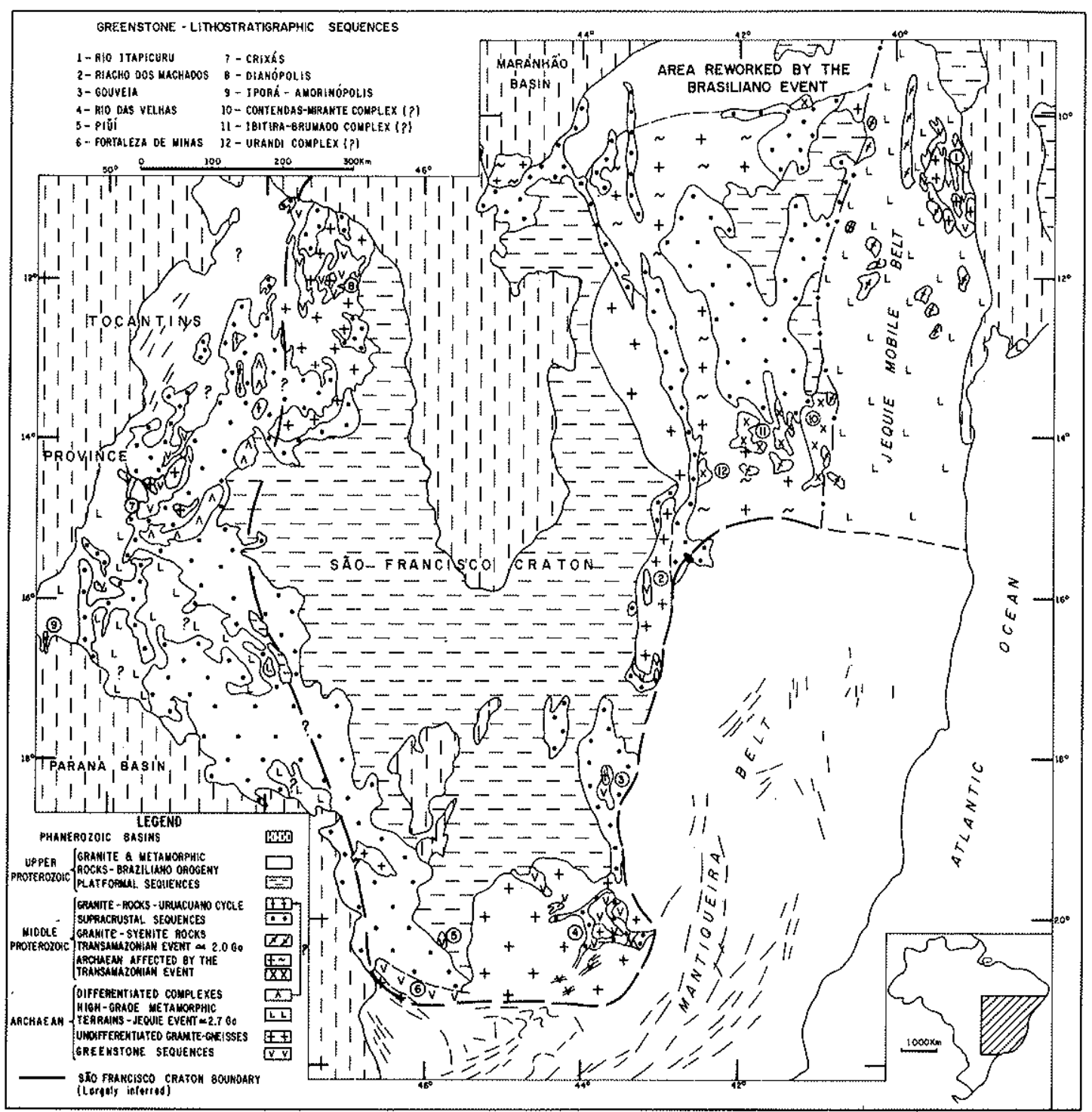

Figure 2 - Localization of Greenstone-litostratigraphic sequences associated of the Säo Francisco Craton

(Figueiredo 1980) with the low-grade (upper greenschist facies) Rio Itapicuru sequence (Fig. 2).

The Rio Itapicuru sequence, a partially reworked greenstone belt, is restricted to a synclinorium with a length of approximately $100 \mathrm{~km}$. The poorly preserved volcano-sedimentary assemblage consists of three major lithostratigraphic units: a Mafic Metavolcanic Unit, a Felsic Metavolcanic Unit and a Metasedimentary Unit A gneissic-granite to granodiorite bodies also occur (Kishida 1979, Kishida \& Riccio 1980). Metatholeiitic volcanics are abundant in the basal Mafic Unit, while intermediate pyroclastics are essential components of the overlying Felsic Unit. The Metasedimentary Unit includes conglomerate, arkose, greywacke, and siltstone.

The high-grade metamorphic rocks of the southern part of the belt form the so-called Jequié Complex (Cordani 1973), which includes granulites of various compositions, minor marble horizons and carbonate-rich lenses.

Although geochronological data are relatively abundant for the entire belt, the most reliable determinations were presented by Cordani \& Iyer (1979), based on a review of numerous $\mathrm{Rb}-\mathrm{Sr}$ ages from granulitic rocks of the Jequié Complex. These latest results suggest the presence of three distinctive sets of radiometric ages probably related to đifferent events, i.e. a pre-Jequié cycle of approximately $3.2 \mathrm{Ga}$, interpreted as an older basement, the Jequié event at $\sim 2.7 \mathrm{Ga}$, and a set of younger ages between 2.45 and $2.3 \mathrm{Ga}$ of rather doubtful interpretation.

To the west, the Jequié belt is flanked by a poorly exposed gneiss-migmatite assemblage (Pedreira et al. 1978) affected by the Transamazônico event $(\sim 2.0 \mathrm{Ga})$ and generally referred to as the Paramirim Complex. It is difficult to define the boundary between these two major geotectonic units, which are separated by a transitional zone with a mixture of high-grade metamorphic rocks from both complexes.

Intensive magmatic activity developed in the Paramirim Complex, during the Transamazônico cycle, with the generation of numerous granite, granodiorite and syenite bodies intruding the gneiss-migmatite assemblage. In the southern part of this area, several rather small complexes of uncertain association and age, such as the Contendas. 


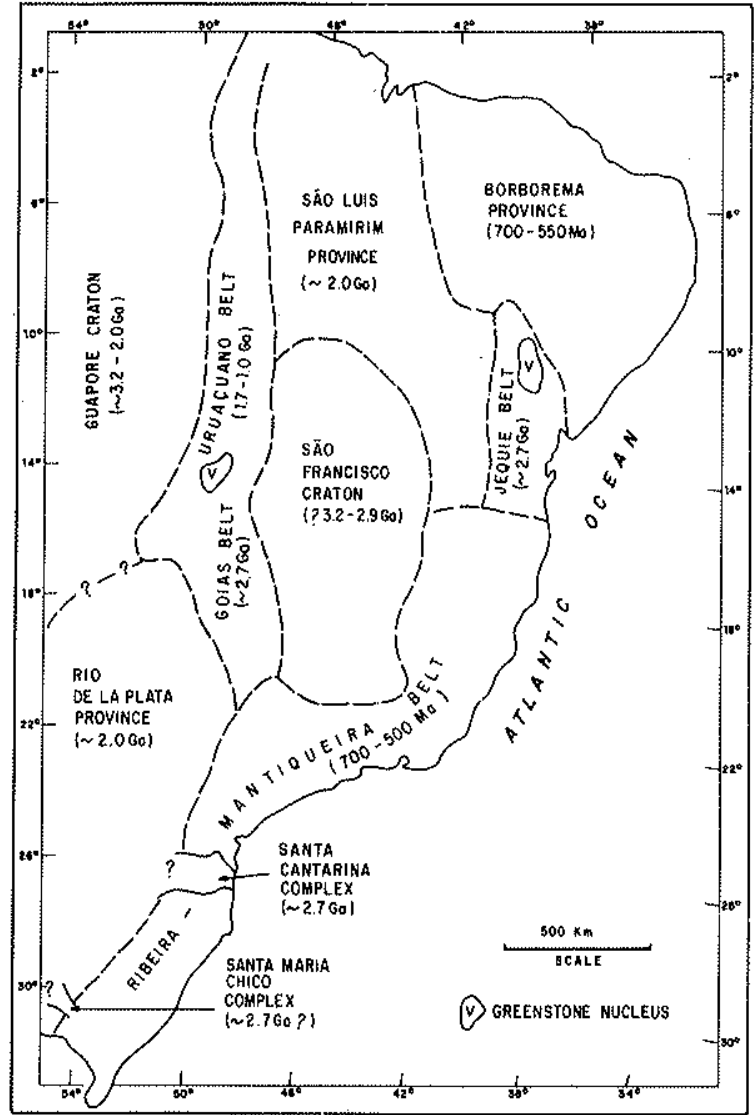

Figure 3 - Geotectonic outline of eastern Brazil

Mirante, Ibitira-Brumado and Urandi complexes (Fig. 2), are exposed as relic volcano-sedimentary sequences within the Transamazônico granite-gneiss terranes (Mascarenhas \& Silva Sá 1982).

The geochronological pattern of this domain covers a rather wide time span, reflecting the effects of several superimposed events from the early Archaean to the Middle Proterozoic. The Paramirim Complex is partly similar to the Jequie belt and it becomes difficult to determine if this complex represents the western extension of this belt or whether it should be considered as a separate geotectonic unit. Based on certain lithological differences, as well as the grade of metamorphism and structural setting, the author would favour the second option, and this large area between the Jequie Mobile Belt and the São Francisco Craton would constitute the São Luís - Paramirim Province of Transamazônico age (Fig. 3).

The Goiás Mobile Belt This belt is exposed as scattered segments partly covered by supracrustal rocks of the Araxá Group of Middle Proterozoic age, and it is therefore difficult to assess to what extent it represented a major mobile zone between the São Francisco and Guaporé Cratons in the late Archaean. However, it is suspected that a significant portion of the state of Goiás is underlain by high-grade metamorphic lithologies, generally within the granulite facies, belonging to this geotectonic unit (Fig. 2).

Granitic to granodioritic-gneiss, migmatite, granulite, amphibolite, calc-silicate rocks and subordinate marble lenses form the central part of the belt, which has been previously referred to as the Goiás Granulitic Belt (Wernick
\& Almeida 1979, Wernick 1981). The high-grade, more basic assemblage of the Goiannia-Trindade region (Nilson \& Motta 1969), and the high-grade metamorphic rocks mapped in the vicinities of both the Barro Alto and Niquelândia (Tocantins) mafic to ultramafic complexes (Lindenmayer 1970, Baeta et al. 1972, Motta et al. 1972) are also considered to be part of this mobile belt.

The geochronological investigations carried out within the region of Itapirapuã (Tassinari et al. 1981) yielded radiometric ages by the $\mathrm{Rb} \cdot \mathrm{Sr}$ method of $2651 \pm 27 \mathrm{Ma}$, related to the Jequié tectonothermal event.

Although numerous mafic to ultramafic differentiated intrusions, including the three largest bodies of Barro Alto, Niquelândia (Tocantins) and Cana Brava are present within the area occupied by the Goiás Mobile Belt (Fig. 2), there is insufficient geological evidence as yet to support their probable Archaean ages, or any genetic relationship of these complexes with the Jequié event. The ages, origins and affiliations of these major intrusions thus remain highly controversial.

The granite-greenstone nucleus of the Tocantins Province The Tocantins Province is an extensive and geologically complex structural domain in central Brazil, including a variety of Precambrian stratigraphic units. The presence of greenstone relics within the Tocantins Province is a common feature in numerous areas, occupied by older rocks underlying the Araxá Group lithologies, but only two of them present sufficient lithostratigraphic elements to merit separate description, namely the Crixás and the Iporá greenstone belts (Fig. 2). These belts are bounded by the high-grade metamorphites of the Goiás mobile belt to the east, while the Crixás belt is bordered to the west by basement with extensive shearing and reworking in the late Precambrian.

The Crixás greenstone sequence is particularly significant as it contains substantial amounts of komatiitic rocks within three slightly arcuate belts, trending approximately north-south. It is intruded by granitic rocks and partially covered by the Araxá Group.

Three main stratigraphic units have been recognized (Saboia 1979, Sabóia \& Teixeira 1983) mostly from mapping in the westernmost belt. A relatively thick sequence of approximately $4.5 \mathrm{~km}$ of mainly ultrabasic rocks comprises the Basal Unit, which is characterized by the presence of significant amounts of komatiitic varieties (Kuyumjian 1981) exhibiting spinifex textures and polyhedral jointing (Sabóia \& Teixeira 1980 et al. 1981).

A Middle Unit composed mainly of metatholeiites, with interbeds of graphite schist, iron formation, and quartzsericite schist, is mainly exposed to the south of the town of Crixás. Towards the north, this unit is flanked by a metasedimentary succession of quartz-sericite schist, chert, graphitic schist, banded iron-formation and carbonate rocks which together constitute the Top Unit.

The intrusive granites, which occupy the areas between the volcano-sedimentary belts, have a radiometric age of $2929 \pm 105 \mathrm{Ma}(\mathrm{Rb}-\mathrm{Sr}$ reference isochron, Tassinari \& Montalvão 1980).

The Iporá belt, which is exposed in separate outcrops, partly covered by Proterozoic and Devonian sediments, presumably extends for about $30 \mathrm{~km}$ in a north-south 
direction and consists of mica schists, banded iron-formation and scattered outcrops of massive metatholeiites, and minor acid-intermediate volcanics and tuffs. The sequence also includes a differentiated mafic to ultramafic body outcropping south of Iporá.

Although the cover rocks of the Araxá Group preclude the investigation of the exact relatonship between these low-grade metamorphosed greenstone sequences and the gneissic-granulitic rocks of the Goiás belt, it also seems that both metamorphic facies coexist in a relatively small area, resembling the coexistence of the Rio Itapicuru greenstone sequence within the Jequié mobile belt. Thus the Crixás and Iporá greenstone sequences are interpreted as Archaean segments belonging to an earlier cratonic domain, which was largely reworked by the late Archaean Jequié tectonothermal event and subsequent rejuvenation Proterozoic.

The Santa Catarina Complex The presence of an ancient nucleus with Archaean radiometric ages has been confirmed in Santa Catarina State of southern Brazil (Fig. 1). Although high-grade metamorphic rocks were earlier described by Albuquerque et al. (1971), Hartmann (1976) and Almeida et al. (1976), it was only during recent studies, carried out by Hartmann et al. (1979) and Silva \& Dias (1981), that these rocks were recognized as an integral part of an ancient mobile zone and subsequently termed the Santa Catarina Granulite Complex.

The outcrop area of this complex is rather small, not exceeding $9,000 \mathrm{~km}^{2}$, but it may continue towards the west under the Parana basin, while the high-grade metamorphites in Rio Grande do Sul State some $600 \mathrm{~km}$ to the south and could also form part of the same domain. To the north and south the complex is flanked by the late Precambrian sequences affected by the Brasiliano cycle.

This high-grade metamorphic complex comprises a suite of rocks in which leucocratic granulitic gneisses are the most common lithology, probably representing up to $80 \%$ of the suite, accompanied by metaquartzites, calcsilicate rocks, oxide-facies banded iron-formation, and mafic to ultramafic bodies, with minor kinzigites and anorthosites. The metamorphic mineral assemblage of these rocks indicates that the complex was affected by granulite to amphibolite facies regional metamorphism during the Jequie cycle, since the available $\mathrm{Rb}-\mathrm{Sr}$ radiometric data from granulitic gneisses indicate an approximate age of 2.7 Ga (Hartmann et al. 1979, Kaul \& Teixeira 1982).

The Santa Maria Chico Complex In the State of Rio Grande do Sul, granulite facies metamorphic rocks appear in several as also poorly investigated segments in a relatively small area (Fig. 2) between the late Precambrian units and the Paraná basin (Nardi \& Hartmann 1979, 1980, Hartmann \& Nardi 1980). These various segments, which together comprise the Santa Maria Chico Complex, are separated by granite intrusions belonging to the Brasiliano cycle $(\sim 550$ $\mathrm{Ma}$ ) and are also partially covered by a Eopalaeozoic volcano-sedimentary molassic sequence. The granulitic rocks may possibly extend for a considerable distance under the Paraná basin sediments.

The most important lithological component of the complex is formed by quartz-felspar gneisses, which mainly show granoblastic rather than typical granulitic textures.
Basic gneisses, with ultrabasic and anorthositic intercalations, and garnet-rich sillimanite gneisses, are present in reduced quantities. In addition, charnockitic rocks have been identified in some of the high-grade metamorphic segments (De Ros \& Fernandez 1981).

DISCUSSION The data compiled and reviewed in this study indicate the presence of several domains older than $2.5 \mathrm{Ga}$ within the eastern region of Brazil. However, only one of these domains, the São Francisco Craton, of rather small size, seems to indicate all the relevant features pertaining to a cratonic area as defined by Anhaeusser et al. (1969) and Anhaeusser (1975).

In contrast with many ancient cratonic areas in other continents, the greenstone nuclei enclosed within the São Francisco Craton present, in general, poorly preserved stratigraphic sequences, occurring mostly as relics, with reduced amounts of volcanics, especially of komatiitic and acid composition. Conversely, they contain a significant contribution from aquagene tuffs and clastic and chemical sediments. In addition, partial removal of some lithostratigraphic units in these successions seems to have taken place during the emplacement of gneissic tonalite intrusions and granitic piutons, during a period of intense magmatic activity, which, according to available geochronological data, could have started prior to $3.2 \mathrm{Ga}$ and lasted for at least $400 \mathrm{Ma}$, since it probably ceased about $2.8 \mathrm{Ga}$.

The remainder of the presently known Archaean terranes of eastern Brazil, i.e. the Jequié and Goiás belts, and the Santa Catarina and Santa Maria Chico complexes, have geological characteristics typical of mobile zones, similar to those described by Anhaeusser et al. (1969) Mason (1973), McGregor (1973), Park (1973), Arhaeusser (1975), Kröner (1977) and Windley (1981). However, the existence within the high-grade metamorphic terranes of the Jequie and Goiás belts of low-grade granite-greenstone nuclei with relatively well preserved stratigraphic sequences, seems to be a notable feature of these two mobile zones.

Intense reworking effected by the superimposition of at least two major Precambrian tectono-thermal events, namely the Jequié and Transamazônico, equivalent respectively to the Limpopo-Liberia and Eburnian events in Africa, was probably responsible for the obliteration of a substantial portion of the early granite-greenstone terranes, and only isolated greenstone relics were preserved.

The subsequent development of other mobile belts during the Uruaçuano (1.7-1.1 Ga) and Brasiliano (750-550 $\mathrm{Ma}$ ) cycles, in areas partly underlain by Archaean terranes, reduced the extent of these terranes considerably, producing a rather fragmentary pattern. Nevertheless, a geological reconstruction showing the distribution of these early Precambrian terranes (Fig. 3) can still be attempted, despite the restrictions caused by the superimposition of tectonothermal events and also by the lack of good exposure.

Features such as transitional boundaries, fragmentary patterns, and poorly preserved greenstone sequences, partially distinguish the Brazilian Archaean terranes from the better preserved major Archaean domains of other continents.

Acknowledgements The author would like to thank Mr. P. Hildred for critically reading, correcting and 
improving the final manuscript. Sincere appreciation is also due to Mrs. Regina Pereira Rego for the typing, and to the B.P. Mineração Ltda., drafting department for producing the figures. I also would like to thank B.P. Mineração Ltda., Brazil, for the help received during the field work and for allowing me to publish the results.

\section{REFERENCES}

ALBUQUERQUE, L.F.; ARIOLI, E.; DIAS, A.; KIRCHNER, C.A. - 1971 - Geologia das Quadriculas de Blumenau e Joinville, SC. Porto Alegre. DNPM-CPRM. 101 p. (unpubl.).

ALMEIDA, F.F.M. - 1967 - Origem e evolução da plataforma brasileira. DNPM 36 p. (Boletim 241).

ALMEIDA, F.F.M. - 1977 - O cráton đe São Francisco. Rev. Bras. Geoc., 7(4): 349-364.

ALMEIDA, F.F.M.; HASUI, Y.; BRITO NEVES, B.B. - $1976-$ The Upper Precambrian of South America. Bol. Inst. Geol, USP, 7:45-80.

ANHAEUSSER, C.R. - 1975 - Precambrian tectonic en vironments. Ann. Rev, Earth Planet. Sci., 3:31-53.

ANHAEUSSER, C.R.; MASON, R.; VILJOEN, M.J.; VILJOEN, R.P. -1969 - A reappraisal of some aspects of Precambrian Shield Geology, Bull. Geol. Soc. Am., 80:2175-2200.

BAETA JR., J.D.A., FIGUEIREDO, A.N.; SOUZA, E.P. DE MELLO, J.C.R. - 1972 - Projeto Goianésia-Barro Alto. Goiânia, CPRM. 129 p. (unpubl.).

BARBOSA, O. - 1970 - Geologia Econômica de Parte da Regiáo do Médio Sáa Francisco, Nordeste do Brasil. DNPM, $98 \mathrm{p}$ (Boletim 140).

BERBERT, C.O. - 1980 - Complexo Basal Goiano. In: CONGR. BRAS. GEOL., 31, Camboriú, 1980. Anais. . Camboriú, SBG. vol. 5, p. $2837-2848$.

BERNASCONI, A. - 1983 - The Archaean terranes of central eastern Brazil. A review. Precambrian Res., 232:107-131.

BIONDI, J.C. \& SCHRANK, A. - 1980 - Sequência Vulcânica Calco-Alcalina em Piữ (MG) - Consideraçōe para identificaç̃̃o. In: CONGR. BRAS. GEOL., 31, Camboriú, 1980. Anais. . . Camboriú, SBG. vol. 4, p. 1933-1944.

CORDANI, U.G. - 1973 - Evolução Geológica Precambriana da Faixa Costeira do Brasil, entre Salvador e Vitória. São Paulo, USP. $98 \mathrm{p}$. Thesis, Inst. Geociências, USP.

CORDANI, U.G. \& IYER, S.S. - 1979 - Geochronological investigations on the Precambrian granulitic terrain of Bahia, Brazil. Precambrian Res., 9:255-274.

CORDANI, V.G. \& TEIXEIRA, W. - 1979 - Comentários sobre as determinacốes geocronológicas existentes para as regióes das Folhas Rio de Janeiro SF.23, Vitoria SF-24 e Iguape SG-23. DNPM. p. 175-207.

COTA, L.A.M.et alii - 1976 - Projeto Leste do Tocantins-Oeste do Säo Francisco; relatório final-fase v. Prospec. DNPM/CPRM. 300 p. (Unpubl.).

DE ROS, L.F. \& D'AVILA FERNANDEZ, L.A. - 1981 - Rochas charnoquiticas no escudo sul-rio-grandense. Ac. Geol. Leop., $5: 25-44$.

DORR, J.V.N. - 1969 - Physiographic, stratigraphic and structural development of the Quadrilátero Ferrffero, Minas Gerais, Brasil. U.S. Geol. Surv., Prof. Pap. 641-A: 110 p.

DORR, J.V.N. GAIR, J.E.; POMERENE, J.B.; RYNEARSON G.A. - 1957 - Revisáo da estratigráfica pré-cambriana do Quadrilatero Ferrifero. Belo Horizonte, DNPM, 31 p. (Avulso 81 ).

FIGUEIREDO, M.C.H. - 1980 - Geochemistry of high grade metamorphic rocks, northeastern Bahia, Brazil. London. $221 \mathrm{p}$. (Thesis, Univ. Western Ont. London, Ont. unpubl.)

FRITZONS, O.; BIONDI, J.C.; CHABAN, N. - 1980 - Geologia da Região de Piâi (MG). In: CONGR. BRAS. GEOL., 31, Camboriú, 1980. Anais. . Camboriú, SBG. vol, 5, p. 2906-2917.

FUJIMORI, S. - 1968 - Granulitos e charnockitos de Salvador, Bahia. An. Acad. bras. Ciênc., 40:181-202.

HARTMANN, L.A. - 1976 - Ocorrência de granulitos em Luiz Alves, SC. In: CONGR. BRAS. GEOL., 29, Ouro Preto, 1976. Resumo... Ouro Preto, SBG.

HARTMANN, L.A.; SILVA, C.L.; ORLANDI Fọ, V. - 1979 Complexo granulítico de Santa Catarina, descrição e implica- ções genéticas. Ac. Geol. Leop., 3: 93-112.

HARTMANN, L.A. \& NARDI, L. -1980 - O cinturão granulítico atlântico nos estados do Rio Grande do Sul e Santa Catarina. Ac. Geol. Leop., 4:3-12.

HERZ, N. - 1970 - Gneissic and igneous rocks of the Quadrilátero Ferrifero, Minas Gerais, Brazil. U.S. Geol. Surv., Prof. Pap., 641B: $55 \mathrm{p}$.

HERZ, N. - 1978 - Metamorphic Rocks of the Quadrilátero Ferrífero, Minas Gerais, Brasil. U.S. Geol. Surv., Prof. Pap., 641-C: $81 \mathrm{p}$.

KAUL, P.F.T. \& TEIXEIRA, W. - 1982 - Axchaean and eariy Proterozoic complexes of Santa Catarina, Paraná and São Paulo states south-southeastern Brazil: an outline of their geological evolution. Rev. Bras. Geoc., 12 (1-3): 172-182. (ISAP).

KISHIDA, A. - 1979 - Caracterizaçäo Geológica e Geoqutmica das Sequências vulcano-sedimentares do médio Rio Itapicuru, Bahia. Salvador. 106 p. (Thesis, Inst. Geoc. Univ. Fed. Bahia. Unpubl.)

KISHIDA, A. \& RICCIO, L. - 1980 - Chemostratigraphy of lava sequences from the Rio Itapicuru Greenstone Belt, Bahia State, Brazil. Precambrian Res., 11:161-178.

KRONER, A. - 1977 - Problems of correlation in precambrian mobilebelts. In: ERMANOVICS, I.F. \& McEwen, G. Eds. Proceedings of a Seminar pertaining to the Limpopo mobile belt. Botswana. Geol. Surv. Bull., 12:9-27.

KUYUMJIAN, R.M. - 1981 - Geologia e Mineralizaçöes Aurtferas do "Greenstone Belt" da Faixa Crixás - GO. Brasilia, 67 p. (Thesis, Univ. de Brasília, Dept. de Geociências, nọ 17. Unpubl.)

LINDENMAYER, D.H. - 1970 - Relatório anual da seç̃o de geologia e Mineralogia, Projeto Niquelândia. Goiânia, DNPM, p. 8-36 (unpubl.).

MASCARENHAS, J.F, - 1979 - Estruturas do tipo "greenstone belt" no leste da Bahia. Salvador. (Geologia e Recursos Minerais do Estado da Bahia. Textos Básicos, 2:25-53).

MASCARENHAS, J.F. \& SILVA SÄ, J.H. - 1982 - Geological and metallogenic patterns in the Archaean and early Proterozoic of Bahia State, eastern Brazil. Rev. Bras. Geoc., 12 (1-3): 193 . 214. (ISAP).

MASON, R. - 1973 - The Limpopo mobile belt-southern Africa. Phil. Trans. Roy. Soc., London, Ser. A, 273:463-485.

MCGREGOR, V.R. - 1973 - The early Precambrian gneisses of the Godthaab district, West Greenland, Phil. Trans. Roy. Soc., London, Ser. A, 273: 343-358.

MOTTA, J., ARAUJO, V.A.; OGUINO, K. $-1972-$ Projeto Niquelândia, Relatório Final. Goiânia, CPRM. 244 p. (unpubl.).

NARDI, L. \& HARTMANN, L.A. - 1979 - O comple xo granulítico Santa Maria Chico do escudo sul-rio-grandense. Ac. Geol, Leop., 3:45-75.

NARDI, L. \& HARTMANN, L.A. - 1980 - Estudo geoquímico de rochas granulíticas do oeste do escudo sul-rio-grandense. Ac. Geol. Leop., 4:3-18.

NILSON, A.A. \& MOTTA, J. - 1969 - Geologia da área GoiâniaTrindade, Goiás. Rio de Janeiro, DNPM. 95 p. (Buletim 133).

OLIVEIRA, E.P.; LIMA, M.I.C.; CARMO, U.F.; WERNICK, E. 1982 - The Archaean granulite terrain from east Bahia, Brazil. Rev. Bras. Geoc., 12(1-3):356-368. (ISAP).

PARK, R.G. - 1973 - The laxfordian belts of the Scottish mailand. In: PARK, R.G. \& TARNEY, J, Eds. The early precambrian of Scotland and related rocks of Greenland. Univ. Keele. p. 65-76.

PEDREIRA, A.J. et alii - 1978 - Inventário de reavaliação de cothecimento geológico da parte central do Cráton de São Francisco. In: REUNIĀO PREPARATÓRIA para o SIMPOSIO sobre o CRÁTON DE SÃO FRANCISCO E SUAS FAIXAS MARGINAIS. Bahia, 1978. Anais... Bahia, SBG/Núcleo da Bahia. p. 67-136. (Publicação Especial, 3).

SABOIA, L.A. - 1979 - Os greenstone Belts de Crixás e Goiás-GO. Bol. Inf., 9:43-72. 
SABÓIA, L.A. \& TEIXEIRA, N.A. - 1980 - Lavas Ultrabásicas da Universidade Basal do greenstone belt de Crixás (GO): Uma nova classe de rochas ultrabásicas no Estado de Goiás. Rev. Bras. Geoc., 10:28-42.

SABOIA, L.A. \& TEIXEIRA, N.A. - 1983 - Ultramafic flows of the Crixás greenstone belt, Goiás - Brasil. Precambrian Res., 22: $23-40$.

SIGHINOLFI, G.P. - 1970 - Investigations into the deep level of the continental crust: Petrology of the granulite facies terranes of Bahia (Brazil). Atti Soc. Tosc. Sci. Nat., Mem. A-77: 327-341.

SILVA, L.C. \& ABREU DIAS, A. - 1981 - Os segmentos mediano e setentrional do escudo caterinense: I, geologia. Ac. Geol. Leop., 5: 3-118.

SILVA, L.C. \& DIAS, A.A. - 1981 -- Os segmentos mediano e setentrional do escudo catarinense; Il, organização e evolução geotectônica. Ac. Geol. Leop., 5: 121-140.

TASSINARI, C.C.G. \& MONTALVÃO, R.M.G. - 1980 - Estudo geocronológico do Greenstone Belt Crixás. In: CONGR. BRAS. GEOL., 31, Camboriú, 1980. Anais. . Camboriú, SBG. vol. 5, p. 2752-2759.

TASSINARI, C.C.G.; SIGA JR., O.; TEIXEIRA, W. - 1981 - Panorama Geocronológico do Centro-Oeste Brasileiro: Soluçōes, Problemáticas e Sugestões. In: Simp. Geol. do Centro-Oeste, 10 Goiânia, 1981. Ata. . . Goiânia, SBG. p. 93-114.
TEIXEIRA, N.A. \& DANNI, J.C.M. -1979 - Geologia da raiz de um greenstone belt na porção sudoeste do Cráton São Francisco. Rev. Bras. Geoc., 9: 17-26.

TEIXEIRA, N.A. \& DANNI, J.C.M. - 1979 - Petrologia das lavas ultrabásicas e básicas da sequiência vulcano-sedimentar Morro do Ferro, Fortaleza de Minas (MG). Rev. Bras. Geoc., 9: 151-158.

TEIXEIRA, N.A. et alii - 1981 - Estruturas e texturas das lavas ultrabásicas do Greenstone Belt de Crixás e Goiás. Bol. Inf., 10:34-87.

WERNICK, E. - 1981 - The archaen of Brasil. In: MABESONE, J.M.; BRITO NEVES, B.B.; SIAL, A.N. Eds. The Geology of Brasil Earth Sci. Rev., 17: 31-48.

WERNICK, E., \& ALMEIDA, F.F.M. - 1979 - The geotectonic environments of Early Precambrian granulites in Brazil. Precambrian Res., 8:1-17.

WINDLEY, B.F. - 1981 - Precambrian rocks in the light of the plate tectonic concept. In: KRONER, A. Ed. Precambrian plate tectonics. Amsterdam, Else vier, p. 1-16.

O velho mundo da laplaciana certeza está morto e sem possibilidade de volta. O desafio enfrentado pelos cientistas modernos e outras pessoas é operar racionalmente numa área de irredutivel incerteza.

MANUSCRITO Revisão aceita em 17 de janeiro de 1985

Robert G. Colodny, Introdução de Faces of Science, de Nalimov, ISI Press, 1981. 